\title{
ANALYSIS OF COST AND COVERAGE OF GOVERNMENT FINANCED PRIMARY HEALTH CARE SERVICES IN TANZANIA
}

\author{
J. L. DE VRIES \\ Department of Health Planning and Administration, School of Public Health, The University of Michigan, \\ Ann Arbor, MI 48109, U.S.A. \\ T. K. BELDING \\ Economic Products, ADP Network Services. Ann Arbor. MI 48106, U.S.A. \\ and
}

S. H. RAJAB

MCH Services, Ministry of Health, Dar es Salaam, Tanzania

(Received 8 July 1982)

\begin{abstract}
A method for cost analysis is presented and applied to Primary Health Care Services in Tanzania. Primary care utilization figures are combined with budget and cost data to arrive at estimates of per capita and per visit cost. Data for analysis of geographical coverage, health care needs, and utilization are most readily available for the $\mathrm{MCH}$ sector of Primary Health Care Services, the most important health care sector in LDCs, which is used in this paper as a proxy for estimating health care needs and utilization. The importance of separating appropriately identified investment costs from recurrent costs is illustrated. Speedy implementation of health care for all requires assistance for investment costs, the recurrent costs of appropriately designed Primary Health Care Services being within the reach of developing nations themselves.
\end{abstract}

\section{INTRODUCTION}

Tanzania (Mainland), with a land area of $937,062 \mathrm{~km}^{3}$ and a population of 17.0 million, has a very dispersed population. Overall population density of $17.5 / \mathrm{km}^{2}$ ranges per region from 8 to $69 / \mathrm{km}^{2}$, with Dar es Salaam having a population density of $707 / \mathrm{km}^{2}$. The population in rural areas is estimated at 14 million. Through the "Arusha Declaration" of 1967 (Tanzania's blueprint for national, social and economic transformation), the Government of Tanzania initiated an overall development process for basic services, e.g. education, water supply and health services, to the whole population, necessitating concentration of the previously even more dispersed population into 8000 Ujamaa villages. Each Ujamaa village of around 1500 population is organized into blocks of ten households, each with a Ten Cell Leader[1]. By 1979, some 6000 of the over 8000 existing villages had contracted for incorporation in this overall development process.

Rural health services in Tanzania have developed historically $[2,3]$ with an emphasis on curative care; since 1965 , this emphasis has been redirected to preventive health activities. By 1967, the number of Rural Dispensaries-still the primary care component of the Tanzanian Health Care System-had increased to about 1200. Their staffing had, until 1967 , been limited to Dispensary Assistants or, more often, dressers with limited training in outpatient care in hospitals.

The development process initiated in 1967 includes considerable redirection of emphasis towards rural health manpower. New categories of health workers were added for the Rural Dispensary (RD) and Rural Health Center (RHC) levels, and central coordination of primary health care worker training was initiated (Table 1).

On the average, five to six villages are organized into Wards, each Ward having an RD. These Dispensaries are increasingly directed by a Rural Medical Aid (50\% in
1979), and staffed further by a newly-created category of $\mathrm{MCH}$ Aids (again about $50 \%$ in 1979). In $50 \%$ of the Wards, an even more recently established category, the Health Auxiliary, is assigned to the Ward committee for environmental improvement.

On average, four to five Wards are organized into a Division, each to eventually have an RHC with a Medical Assistant as team leader and staffed primarily by NurseMidwives and, occasionally, Rural Medical Aids. (The Division will be used later in the paper as the basic unit for cost analysis of rural health services.) At present, as indicated later, the ratio of RHCs to RDs is about $1: 8$. Three to five Divisions are grouped in Districts, each with a District Hospital, in which a District Medical Officer supervises all health facilities of the "basic health unit"[1] and is responsible to the District Area Commissioner through a District Development Director. In the 96 Districts, the District Hospital serves as the top referral level.

In the early 1970s, an additional category of Village Medical Worker was established, a program started but temporarily suspended, in which young literate villagers were trained for three to six months. The trainees were not, however, adequately supported by the villages and many sought employment elsewhere. It is the Government's intention to reactivale this program. Training will be directed to a more established category of villager, such as middle-aged married women.

The restructuring of the health services since 1967 was accompanied by a gradual shift in emphasis in the expenditure of the Government; an allocation of $80 \%$ to hospital services in 1970-71 was reduced by 1975 to $60 \%[1]$.

Since indicators and data for the assessment of needs for and coverage of $\mathrm{MCH}$ services are in most countries, and were certainly in Tanzania, more readily available than for other components of Primary Health Care Ser- 
Table 1. Organization and characteristics of personnel used in the Tanzanian rural health care system

\begin{tabular}{|c|c|c|c|c|c|c|}
\hline \multirow[b]{2}{*}{$\begin{array}{l}\text { Heal th personnel Category } \\
\text { for Three lichelons }\end{array}$} & \multirow[b]{2}{*}{$\begin{array}{l}\text { Basic } \\
\text { Qualifications }\end{array}$} & \multicolumn{3}{|c|}{ Spectalized Trauning } & \multirow[b]{2}{*}{$\begin{array}{l}\text { Mnamim } \\
\text { Salary } \\
\text { US \$per } \\
\text { Year }\end{array}$} & \multirow[b]{2}{*}{$\begin{array}{l}\text { Scope } \\
\text { of } \\
\text { Actuvity }\end{array}$} \\
\hline & & Durations & $\begin{array}{l}\text { Costs } \\
\text { US \$per } \\
\text { Graduate }\end{array}$ & $\begin{array}{l}\text { Number } \\
\text { of } \\
\text { Schools } \\
1977\end{array}$ & & \\
\hline \multicolumn{7}{|l|}{ Ward Level } \\
\hline $\begin{array}{l}\text { Health Auxiliary (AUX) } \\
\text { Dispensary } \\
\text { Rural Medical AId (RMA) } \\
\text { MClild } \\
\text { Village Midwife (VM) } \\
\text { Aursing Auxiliary (AUX) }\end{array}$ & $\begin{array}{l}\text { Grade } 7 \\
\text { Grade } 7 \\
\text { Grade } 7 \\
\text { Grade } 7\end{array}$ & $\begin{array}{l}3 y \mathrm{rs} \\
18-24 \text { mos } \\
3-9 \text { mos } \\
\text { on job tr }\end{array}$ & $\begin{array}{r}1800 \\
4500 \\
- \\
-\end{array}$ & $\begin{array}{l}15 \\
12 \\
- \\
-\end{array}$ & $\begin{array}{l}80 \geq 5 \\
700 \\
700 \\
590\end{array}$ & $\begin{array}{l}\text { Communzty } \\
\text { and } \\
\text { lrimary } \\
\text { lealth } \\
\text { Care }\end{array}$ \\
\hline \multicolumn{7}{|l|}{ Division Lovel } \\
\hline $\begin{array}{l}\text { Nurse } B \\
\text { Rural Medical AID } \\
\text { MCHA1D ( } 2 \text { per RHC) } \\
\text { Pharmacy Auxiliary (AUX) } \\
\text { Microscopist } \\
\text { Nursing Auxiliary }\end{array}$ & $\begin{array}{l}\text { Form IV } \\
\text { Grade } 7 \\
\text { Grade } 7 \\
\text { Grade } 7 \\
\text { Grade } 7 \\
\text { Grade } 7 \\
\text { Grade } 7\end{array}$ & $\begin{array}{l}4 \text { yrs } \\
2 \text { yrs } \\
18-24 \text { mos } \\
6-12 \text { mos } \\
6-12 \text { mos } \\
\text { On job tr }\end{array}$ & $\begin{array}{c}3600 \\
2700 \\
1800 \\
4500^{3} \\
600 \\
600 \\
-\end{array}$ & $\begin{array}{l}10) \\
37 \\
17 \\
- \\
= \\
= \\
-\end{array}$ & $\begin{array}{l}1500 \\
8625 \\
862.5 \\
700 \\
700 \\
700 \\
590\end{array}$ & $\begin{array}{l}\text { Commumity, } \\
\text { Primary. } \\
\text { and Some } \\
\text { Secondary } \\
\text { jlealth } \\
\text { Care }\end{array}$ \\
\hline \multicolumn{7}{|l|}{ District Health Tean } \\
\hline Medical Doctor & $\begin{array}{l}\text { Form } 11 \\
(13 \text { yrs })\end{array}$ & 5 yrs & 25000 & 1 & 3050 & \multirow{5}{*}{ 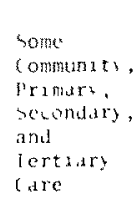 } \\
\hline $\begin{array}{l}\text { Assistant Hedical } \\
\text { Officer (ANO) } \\
\{2-3 \text { per District) }\end{array}$ & $\begin{array}{l}\text { MA }(3-5 \text { yrs } \\
\text { experience })\end{array}$ & $18 \operatorname{mos}$ & 6000 & 3 & 2000 & \\
\hline $\begin{array}{l}\text { Public Health Nurse } \\
\text { (NCH Supervasor) }\end{array}$ & $N / M$ & $9-18 \operatorname{mos}$ & 6000 & - & 20001 & \\
\hline Nurse Nadwife (SRN) & Form IV & 4 yrs & 3000 & - & 1500 & \\
\hline Fublic liealth Nurse B & $\mathrm{N} / \mathrm{M}$ & 18 mos & 4000 & & 1500 & \\
\hline
\end{tabular}

a The relative size of this figure is attrabutable to the fact that the Mch training program focuses anquely on the MCL and thus does nor benefit from cross-subsidization as is the case with most other training programs, particularly those conducted in hospltals. e.g. , for nurses.

vices, this analysis uses $\mathrm{MCH}$ services as a proxy for evaluating health care needs and coverage. A further justification is that the $\mathrm{MCH}$ sector is considered the major contributor to a people's health in LDCs [4]. However, the Cost Analysis section of this paper focuses on overall health care services delivered through RDs and RHCs.

\section{THE MCH SECTOR OF THE PRIMARY HEALTH CARE SYSTEM}

Before 1972, MCH services, such as were provided in a limited number of RDs and in all hospitals, were provided by "Village Midwives" and "Nurse Aids", both variably trained in hospitals (which retained a considerable proportion of their trainees). Recognition of the fact that $\mathrm{MCH}$ services required a much more concerted effort in staff development led in 1974, as first recommended by Titmuss et al.[2], to the establishment of a project for the training of $\mathrm{MCH}$ Aids, initiated by a USAID-assisted project for the construction and staffing of schools for MCH Aids, numbering twelve in 1977 and reaching the planned eighteen in 1979 (Table 1). The USAID-assisted project included strengthening of $\mathrm{MCH}$ services through special training oversees of supervisory personnel and support personnel.

At the two lower echelons, $\mathrm{MCH}$ services were expanded and increasingly staffed by $\mathrm{MCH}$ Aids, as they became available. An $\mathrm{MCH}$ directorate was created at the Ministry of Health, and posts for MCH supervisors were established at Zonal (four Zones), Regional and District levels.

\section{HEALTH CARE' NEEOS}

Available health indicators for 1978 are a crude death rate of seventeen, a crude birth rate of 46 , a crude rate of population increase of $2.9 \%$, an infant mortality rate of 130, and a life expectancy at birth of $47 \mathrm{yr}$ [5]. In spite of the already well established reporting system, no information is available on causes of death in general, nor for causes of death in the first year of life.

On the other hand, the frequency of diarrhoea among the $\mathrm{MCH}$ first attendances $(0-6 \mathrm{yr})$ varied from $19 \%$ in January-June 1976 , to $21 \%$ in July-December 1976 and $25.7 \%$ in January-June 1977. The range of malnutrition diagnosed as underweight (excluding kwashiorkor and marasmus) among these first-time $\mathrm{MCH}$ attendees varied from $18.7 \%$ in the first half of 1976 to $26.8 \%$ in the second half of 1976 and $27.2 \%$ in the first half of 1977 . These frequencies indicate a disturbing degree of malnutrition in the very young [6].

Though age-specific data for other diseases were not available, three of the communicable diseases most common among children (measles, tentanus and meningitis) were responsible for $13.6 \%$ of all causes of deaths in hospitals in 1976.

Measles accounted for $6.6 \%$ of all first MCH atten- 
dance below $6 \mathrm{yr}$ in 1976 and $16.0 \%$ in the first half of 1977. Morley et al. [7] reported case-fatality of measles in hospitals of $5.7 \%$ in 1966 in East Africa. More detailed studies in limited areas confirm the high level of malnutrition [8], skin diseases [9], and anaemia[10]. Deliveries and complications of pregnancy and puerperium accounted for $19 \%$ of all causes of admission to govenment and voluntary agency hospitals in 1976, indicating an unmet need for $\mathrm{MCH}$ services at that time.

The total burden of illness-represented by the number of illness episodes per person per year, or by age-specific incidence of disease-is not available. However, the above-indicated components of ill health together with the high IMR (130), low life expectancy at birth $(47 \mathrm{yr})$, and concentration of preventable diseases in children below $6 \mathrm{yr}$ old and in women of childbearing age provide ample evidence of persisting unmet need for health care in general, and for $\mathrm{MCH}$ services in particular. Even though the combined case fatality in hospitals for pneumonia, malaria and measles had declined remarkably between 1973 and 1976 , from 3.9 to $1.7 \%$ respectively, the number of admissions for these conditions declined much less (from 112,611 to 93,285 or $17.2 \%)[11]$.

\section{HEALTH SERVICE COVKRAGE AND UTHLZATION}

Tanahashi[12] extends the concept of coverage well beyond its most common usage for geographical accessibility and catchment area[13] and includes financial access, socio-cultural and structural barriers of access, effectiveness and efficiency. In the Tanzanian case, where health services are free of charge to the patient and socio-cultural barriers are much less pronounced (and possibly negligible), we limit our analysis of coverage to geographical access, while effectiveness-as measured indirectly by utilization [14]-and efficiency-as implied by cost-are considered separate from coverage.

In Tanzania, the target population for a dispensary is defined as the population living within $2 \mathrm{hr}$ walking distance, or a $10 \mathrm{~km}$ radius (which varies from 2400 to 21,000 people-an average of 7000 population) [1].

With the widely varying population density in Tanzania, average density values are of limited utility, yet do provide a crude perspective. Furthermore determinations of catchment areas [14] do not always recognize that perceptions of walkable distance vary with population density. Among widely scattered population, a $2-3 \mathrm{hr}$ walking distance is often perceived as quite normal, while in densely populated areas a haif hour's walking distance may be perceived as very far. Also, there are obvious gradients in distances traveled to seek health care relative to different illnesses. A patient with an open fracture will travel much farther to seek care than patients with irregular fever or a persistent cough. It is exactly these gradients and the high frequency of minor illnesses that health service designs take into account with regard to planning of decreasingly complex health care capacities toward the periphery.

Tanzania has achieved an unusual outreach of its rural health facilities. In 1969 only $31.9 \%$ of the population in one region lived more than $10 \mathrm{~km}$ away from any health facilities, while in $1978,80 \%$ of the total population were within $10 \mathrm{~km}$ of a medical facility in that region[15]. It is not surprising, therefore, that the reported number of outpatient visits increased from 55 million in 1974 to 66 million in 1977 , or to 4.7 health service contacts per person per year. This is an unusually high utilization rate for most developing countries and, if accurate, would indicate a high degree of accessibility and utility of the health services network and high coverage of the rural population.

\section{UTILIZATION OF MCH SERVICES}

The target population for $\mathrm{MCH}$ services is women of fertile age (15-44 yr) and children of $0-4 \mathrm{yr}$, together $39 \%$ of the total population according to 1975 data[1]. If applied to the 1978 estimated rural population of 14 million, this target population is 5.46 million people.

We arrive (reference Annex 1) at an initial target utilization by this population of $\mathrm{MCH}$ services-at this stage of health service development - of 1.8 visits per person per year $(9.80$ million visits by the target population of 5.46 million) assuming that utilization patterns relate to:

\begin{tabular}{l}
\hline $\begin{array}{l}\text { Millions } \\
\text { of visits }\end{array}$ \\
$\begin{array}{l}\text { Regular immunization of infants (for complete } \\
\text { coverage, } 4 \text { visits per year for children under } 1 \mathrm{yr} \text { ); }\end{array}$ \\
$\begin{array}{l}\text { Partial attendance for infant and childhood diarrhoea } \\
\text { (50\% attendance for a generally-assumed incidence } \\
\text { of } 2-3 \text { diarthoea attacks per year in children under } \\
5 \text {; }\end{array}$ \\
$\begin{array}{l}\text { Attendance of } 50 \% \text { for common childhood diseases } \\
\text { (respiratory infections and skin diseases of at least }\end{array}$ \\
$\begin{array}{l}2 \text { incidents per year for } 0-4 \text { yr of } 1 \text { visit per child } \\
0-4 \text { yr); }\end{array}$ \\
$\begin{array}{ll}\text { Antenatal care of } 2 \text { visits per pregnant woman } \\
\text { (624,000 newborn). }\end{array}$ \\
\hline
\end{tabular}

Utilization of $\mathrm{MCH}$ service activities has been greatly increased since 1975 through the establishment of a new pattern of service delivery at the lower echelons. All women of fertile age and children below 6 yr who report for medical care are first routed through the $\mathrm{MCH}$ section for follow-up of child development, immunizations, pre- and post-natal care and child-spacing services. Further impetus to the development of $\mathrm{MCH}$ services has been provided since 1976 by a nationwide Expanded Programme in Immunization, implemented by regular MCH services with assistance from WHO, UNICEF and several bilateral donors.

As a result, actual attendance for $\mathrm{MCH}$ services increased from 3.1 million in 1976 to an estimated 7 million in 1978 , or 1.3 visits per person per year for the $\mathrm{MCH}$ target population-70\% of the target utilization noted above.

From the above-reported MCH attendance of 1.3 visits per person per year for the target population, though in itself a remarkable achievement in such a short time, one would fear a low coverage of immunization. This is confirmed by the Evaluation Report of the Expanded Programme in Immunization (EPI) by the Ministry, DANIDA, WHO and UNICEF of 1978 based on three districts which reports for Arumeru district a less than satisfactory immunization level, and for Kisarawe and Iringa districts a definitely unsatisfactory immunization level.

From the author's field visits, it was obvious that the $\mathrm{MCH}$ Aids, village midwives and nurse aids in the RDs 
Annex 1. Initial target utilization of $\mathrm{MCH}$ services in rural areas.

\begin{tabular}{|c|c|}
\hline Rural Population & 14 Million \\
\hline Crude Birth Rate & 46 per Thousand \\
\hline Newborn & 644,000 \\
\hline IMR & 130 per Thousand Live Births \\
\hline Population 0-1 (mid-year est.) & 602,140 \\
\hline Population $1 \mathrm{yr}$ old & 560,280 \\
\hline Child Mortality $1-4$ & 40 per Thousand \\
\hline Population 1-4 & $4 \times(1-.04) \times 560,280=2,151,47$ \\
\hline Population $0-4$ & $560.280+2.151 .475=2.711 .755$ \\
\hline Women $15-44$ & $2,748,245$ \\
\hline Total Target Population for $\mathrm{MCH}$ Services & $5,460,000$ \\
\hline Initıal Target Utılization & \\
\hline Immunezation Visits & $4 \times 602,140-2,408,560$ \\
\hline $\begin{array}{l}\text { Infant and Childhood Diarrhoeas } \\
\text { ( } 50^{\circ} \text { at atendance of } 2.5 \text { attacks per child) }\end{array}$ & $.5 \times 2.5 \times 2,711,755=3,389,694$ \\
\hline $\begin{array}{l}\text { Common Childhood Diseases } \\
\text { ( } 50^{\circ} \text { attendance of } 2 \text { incidents) }\end{array}$ & $.5 \times 2 \times 2,711,755=2,711,755$ \\
\hline $\begin{array}{l}\text { Antenatal Care } \\
\text { ( } 2 \text { visits per pregnancy) }\end{array}$ & $2 \times 644,000=1,288,000$ \\
\hline Total Visits by Target Population & $9,798,009$ \\
\hline $\begin{array}{l}\text { Number of Visits per Person per Year } \\
\text { of Target Population }\end{array}$ & $\frac{9,789,009}{5,460,000}=1.79$ \\
\hline
\end{tabular}

were already fully occupied with $\mathrm{MCH}$ attendances, while another large part of the workload for these facilities was outside the $\mathrm{MCH}$ targe population. If teamwork at the RDs were to generate better utilization for $\mathrm{MCH}$ services only for the regular immunization decided by the Ministry of Health, the staffing of the RDs as planned at present should be adequate to cope with the projected workload. For immunizations only, this would consist of four visits for 322 newborn (average. population of 7000 ), or not more than twenty-five immunization visits per week, each visit comprising one to three immunizations.

\section{COST ANALYSIS}

This analysis attempts to separate investment costs from recurrent costs, and to review them over several years. In all development activities, as in the health program studied here, it is important to distinguish between these two cost categories and to try to record their change with time, largely because of the input this information can have to financial planning by host countries and donors. Without adequate provision for both kinds of cost, a program will not likely reach its objectives. A common criteria for development assistance is whether or not host countries will have sufficient resources to finance recurrent expenses once external sources cover initial investments. The presentation of this analysis is intended to assist with a methodology to find out whether-in the case of basic health care programs-the host country will be able to finance recurrent expenses. We provide supporting data for the case of Tanzania.

\section{Methods}

Tables 2 and 3 illustrate the format we found useful for organizing cost data. Distinctions between the groups are in most cases straightforward and can easily be extended from this specific example to the general case. With regard to durable and nondurable goods the principle followed was that, where possible, the purchase cost of durable goods-goods of a long, useful life-was assigned to investment. Rent, operation and maintenance costs were considered recurrent. Cost of initial stocks of nondurable goods-goods which are used up quickly, such as vaccines, uniforms and food-were considered to be investment costs; subsequent replacement purchases were considered recurrent costs.

Training activities were costed as investment if the objective of training was to build up an initial level of staffing, as in a program such as that for MCH Aids, and as recurrent if the objective was to maintain staffing levels of an existing echelon of workers. Maintaining this distinction is not always easy since there is an obvious trend to increase the stock of all primary health workers, rather than maintaining existing levels. However, this method was selected as a good practical approach since cadres of trainees other than MCHA students were for the most part trained in an existing system, i.e. with facilities, teachers, materials already in place, and were adding to or replenishing an existing stock of workers. This was not true in the still nascent MCHA training system.

In any event, placement of individual items is not so important as recoginzing the need to distinguish between initial and recurrent costs and to measure them as accurately as one can, ultimate assignment depending on each specific case. 
Table 2. Macro-level investment and recurrent costs of rural health centers and dispensaries in Tanzania (detail FY 1976/77)

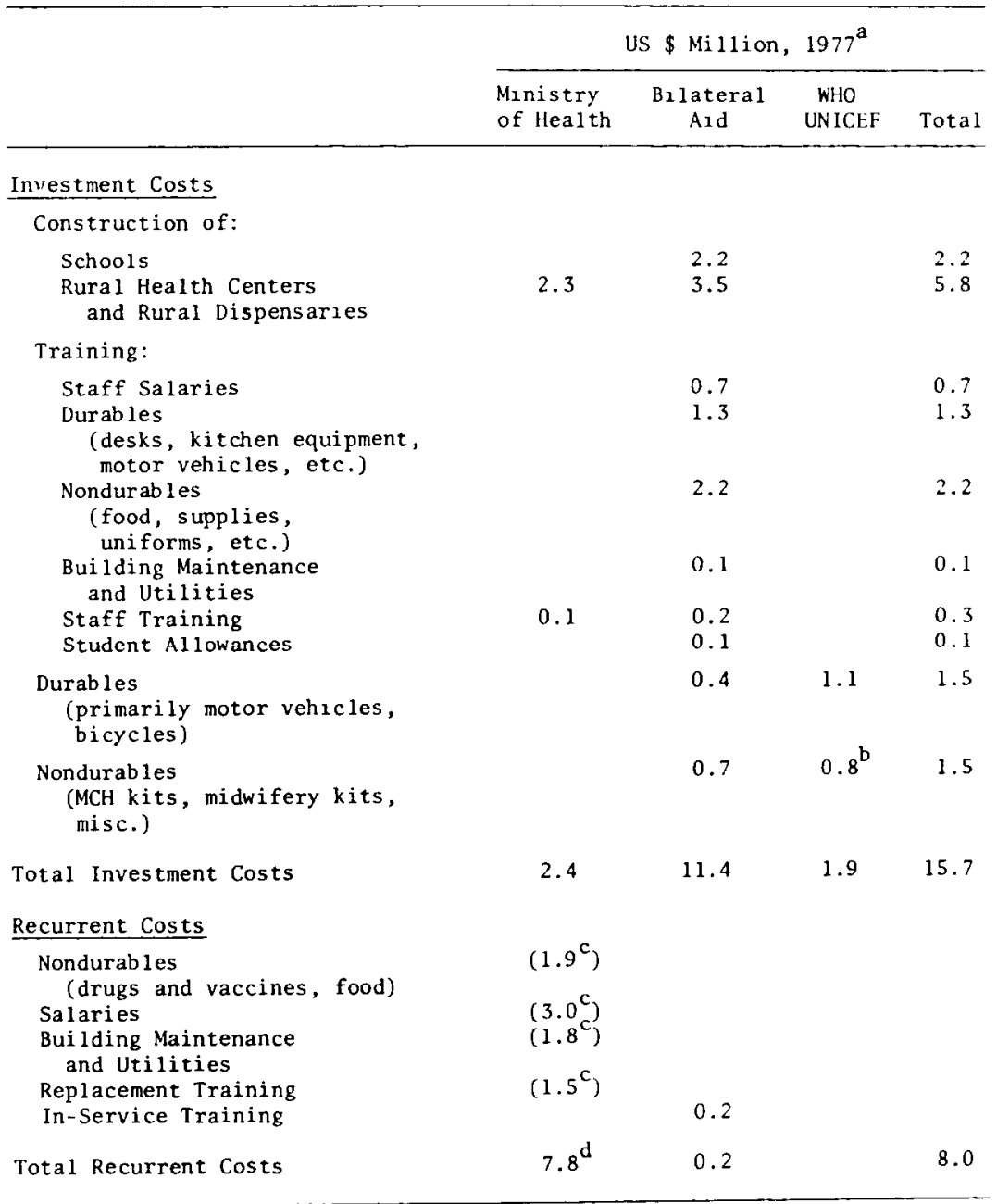

a Calculated using an index at Tanzanian prices from the I.M.F.

b Includes a small percentage of recurrent drug supplies.

c These figures are estimates of actual cost and do not sum to the column total, which is an aggregate budget number. See discussion under "Results of Cost Analysis-Macro Level" and Annex 2.

d Operating Budget, Rural Health Services, Ministry of Health (US $\$$ Million 1977). Results of cost analysis-national aggregate (macro)
level

Investment costs were calculated primarily from expense receipts and source agency estimates; this was true for the costs met by the Ministry of Health (MOH) as well as by external providers. Table 2 shows detail for FY 76/77; Table 3 summarizes 3 yr of data.

Recurrent costs were, on the other hand, not readily available. To overcome this, we have used the MOH operating budget for rural health services as a proxy for the bulk of recurrent cost (the MOH budget covers the major share of recurrent expenses). Other sources include bilateral aid for continuing education seminars, the UN for drugs (see Table 2, note b), and private-mainly religiousgroups (no estimates available). These external providers cover probably no more than $5 \%$ of total current costs outside of the MOH-budget.

If we assume a rural population at the time of 10 million to be served by RHCs and RDs (the remaining 4 million rural population being covered by District Hospitals serving also as RHCs in their Divisions-see next section), then these macro cost data indicate roughly US $\$ 0.80$ per person was being allotted in 1977 for rural health services, or about US $\$ 0.17$ per visit based on 4.7 visits per person per year overall.

In order to check the reasonableness of the budget figure, estimates were calculated for each of the major recurrent costs, and the total was compared to the budget (reference Annex 2). Our estimate came out surprisingly close to the budget-US $\$ 8.2$ million vs $\$ 7.8$ million, respectively - supporting the budget's validity as a proxy cost measure. However, without a breakdown of the budget so that we could compare categories, and lacking data on what was actually spent, we cannot be assured of the validity of the aggregate recurrent cost figures noted in Tables 2 and 3.

In order to estimate more accurately the cost of providing rural health services, we shall in the next section 
Table 3. Macro-level investment and recurrent costs of rural health centers and dispensaries in Tanzania" 1975-1978 (US \$ Million, 1977)

\begin{tabular}{|c|c|c|c|c|c|c|}
\hline & \multirow[b]{2}{*}{$1975 / 76$} & \multirow[b]{2}{*}{$1976 / 77$} & \multirow[b]{2}{*}{$1977 / 78^{b}$} & \multicolumn{3}{|c|}{ Source of Funds } \\
\hline & & & & $\begin{array}{l}\text { Ministry } \\
\text { of Health }\end{array}$ & $\begin{array}{c}\text { B1lateral } \\
\text { Aid }\end{array}$ & $\begin{array}{c}\text { WHO } \\
\text { UNICEF }\end{array}$ \\
\hline \multicolumn{7}{|l|}{ Investment Costs } \\
\hline \multicolumn{7}{|l|}{ Construction } \\
\hline Schools & 1.4 & 2.2 & 0.3 & - & $100 \%$ & - \\
\hline RHCs and RDs & 5.5 & 5.8 & 3.7 & $58 \%$ & $42 \%$ & - \\
\hline Training & 1.9 & 4.7 & 4.0 & $3 \%$ & $97 \%$ & - \\
\hline Durables ${ }^{c}$ & - & 1.5 & 0.2 & - & $31 \%$ & $69^{\circ}$ \\
\hline Nondurables ${ }^{c}$ & 0.5 & 1.5 & 0.3 & - & $62 \%$ & $38^{\circ}$ \\
\hline Total Investment $\operatorname{Cos} t^{\mathrm{d}}$ & 9.3 & 15.7 & 8.5 & $27^{\circ}$ & $67 \%$ & $6 \%$ \\
\hline Total Recurrent $\operatorname{Cos} t^{d, e}$ & 8.3 & 8.0 & 12.0 & $99 \%$ & $1 \%$ & - \\
\hline
\end{tabular}

a In genera1, figures obtained from bilateral aid sources and UN agencies were recorded expenses. As in the previous table, estimates of costs met by the Tanzanian Ministry of Health are based primarily on budget figures.

b Figures reported here are based in part on full-year projections from records available for only the first half of the fiscal year.

c Costs not related to training; durables and nondurables used in tralning are subsumed under "Training."

d When reviewing these investment and recurrent cost data, the reader should bear in mind that one year's investment bears no direct relation to the cost of services provided in that year.

e Primarily the Operating Budget, Rural Health Services, Monistry of Health.

look at a more well-defined unit of the system-the Division level-where the disadvantages of these budgetbased aggregates can be avoided.

\section{Results of cost analysis-division (micro) level}

As mentioned earlier, a Division contains one RHC and an average eight associated RDs, together serving roughly 50,000 people. We assume this to be the typical Division. District hospitals serve as RHCs for the Divisions in which they are located; this is true for approximately one-fourth of all Divisions. Since these hospitals perform many other functions besides those of the typical RHC, this analysis concentrates on those Divisions without a District hospital.

This estimation is also based on:

-cost figures from both the Ministry of Health and bilateral agencies-particularly USAID-for construction, salaries and training;

-estimates of the cost of nondurable and durable goods which were consistent with Ministry estimates and available data;

- staffing patterns and costs as shown in Table 1;

- staff turnover of $15 \%$ per year.

These results (see Table 4) indicate an estimated investment cost of just over US $\$ 5$ per capita and recurrent costs of US $\$ 1.50$ per year per capita (an investment/recurrent cost ratio of $3.5: 1$ ) or roughly US $\$ 0.32$ per visit based on 4.7 visits per person per year.

Estimated investment costs for RHCs and RDs of US $\$ 124,000$ and $\$ 17,000$, respectively, are substantially different from earlier figures of Chagula and Tarimo[1] of US $\$ 84,000$ and $\$ 7300$, respectively. This is no doubt partly due to our inclusion of costs of initial training and durable goods, such as motor vehicles.
Our estimates of RHC and RD recurrent costs-US $\$ 27,000$ and $\$ 6000$, respectively-are close to those of Chagula and Tarimo[1]-US $\$ 21,000$ and $\$ 4200$-for the same facilities in Tanzania, especially when allowing for inflation since that earlier study.

To the right hand side of Table 4 are projections from 1977 to 1981 based on the knowledge that reported utilization of the system has increased roughly $28 \%$ since 1977 , i.e. up to nearly six visits per person per year by 1979 , and on the estimate that this trend will continue, though more moderately. These very simple projections are only intended to give an indication of cost that is in a range consistent with available information, and to serve as an example for financial planners.

\section{Cost discussion}

The investment figures shown in Tables 2 and 3 illustrate the levels of expenditures for the categories listed as well as the significant variation in investment during the period. The overwhelming proportion of these expenditures were for construction and training. The government's primary role in investment was for service facility construction, although these allocations were small in relation to its recurrent budget; UN agencies were most importantly involved in providing durable and nondurable materials; bilateral aid focused on school construction, training and nondurables.

Investment activities have substantially increased in recent years, as indicated by an increase in RHCs from 22 to 161 and RDs from 875 to 2088 between 1961 and 1977. Our macro-level results indicate that during the period 1975-78 (Table 3), investment costs for RHCs and RDs averaged $54 \%$ of total costs, significantly above earlier reports based on both expenditure and budget 
Annex 2. Estimation of macro-level recurrent costs for RHCs and RDs in use, 1976/77 (summarized in Table 2).

Nondurables

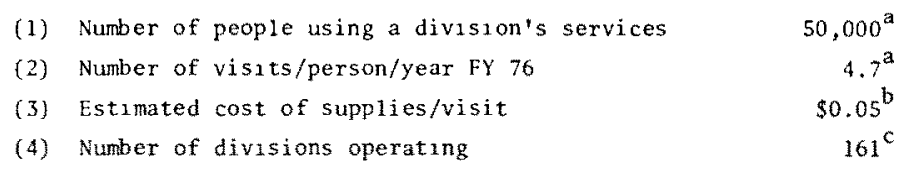

Total estimated cost of nondurables $=(1) \times(2) \times(3) \times(4) \quad \$ 1.9 \mathrm{~m}$

Personnel Costs (reference Table 1)

(5)

\begin{tabular}{|c|c|c|c|c|}
\hline $\begin{array}{l}\text { Personne } 1 \\
\text { Type }\end{array}$ & $\begin{array}{l}\text { Assumed } \\
\text { Number } \\
\text { in Use }\end{array}$ & $\begin{array}{l}\text { Nunber } \\
\text { Yearly } \\
\text { Turnover } \\
(15 \%)\end{array}$ & $\begin{array}{l}\text { Number Yearly } \\
\text { Expansion } \\
\text { to Staff New } \\
\text { Facilities } \\
(17 \%)\end{array}$ & $\begin{array}{l}\text { Trasning } \\
\text { Cost }\end{array}$ \\
\hline AMO & 160 & 24 & 27 & $\$ 6,000$ \\
\hline RMA & $1,400^{c}$ & 210 & 238 & 1,800 \\
\hline PH-B & 160 & 24 & 27 & 4,000 \\
\hline MCHAID/M & $1,400^{\mathrm{c}, \mathrm{e}}$ & 210 & 238 & 500 \\
\hline AUX & 480 & 72 & 82 & 100 \\
\hline
\end{tabular}

Estımated Total Salary $=(5) \times$ (Salaries from Table 1)

$\$ 3.0$

Estimated Replacement Training $=(6) \times(8)$

0.7

Estimated Expansion Training $=(7) \times(8)$

0.8

Total Estimated Personnei Cost

$\$ 4.5 \mathrm{~m}$

Building and Mantenance (reference note a below and Table 4)

$[\$ 5,000 / \mathrm{RHC} \times 161 \mathrm{RHCs}$ operating $]+[\$ 1,000 / \mathrm{RD} \times 1,000 \mathrm{RDs}$ operating $] \$ 1.8 \mathrm{~m}$

\begin{tabular}{ll}
\hline Total Estimated Recurrent Cost & $\$ 8.2 \mathrm{~m}^{\mathrm{f}}$ \\
Operating Budget for Rural Health, $\mathrm{MOH}$ & $\$ 7.8 \mathrm{~m}$
\end{tabular}

${ }^{\star}$ Ministry of Health figures.

'Yudkin[18] reports the cost of drugs per dispensary visit in 1976 at US $\$ 0.025$. We estimate total cost of supplies across dispensaries and health centers as roughly double this figure, or US $\$ 0.05$.

${ }^{C}$ Based on planned staffing pattern as outlined in Table 1 , reported numbers of staff available, and numbers of facilities existing, there appeared to be approximately a $40 \%$ shortage of these personnel. For example, there were 1400 rural medical aids and approximately 1400 acknowledged personnel with the title MCHAID, village midwife or nurse-midwife in the Tanzanian health system in 1977 (Ministry of Health figures). Staffing patterns in Table 1 indicate roughly 2400 of each of these two groups of workers were needed for facilities in existence. This shortage is assumed for costing purposes to indicate that on average, roughly $60 \%$ of existing facilities were operating at planned staffing levels. Since RHCs are more substantial and therefore more likely to be staffed, we assume for costing purposes that virtually all RCHs (161) are operating with close to planned staff, but that only 1000 of the 2088 RDs are operating at their planned level.

${ }^{d}$ From Table 1, except: MCHAID/VM cost refiects note b plus an estimate that the Tanzanian Government by 1977 had assumed approximately $35 \%$ of recurrent MCHAID training costs as part of its cost transfer agreement with USAID, $(\$ 4500) \times(30 \%) \times(35 \%)$ : the AUX cost is a weighted average.

'Approximately $30 \%$ MCHAIDS.

${ }^{\mathrm{f}}$ A similar estimate based primarily on disaggregate recurrent cost figures from Table 4 is close to this figure, and gives more evidence that it is likely to be conservative. 
Table 4. Micro-level* investment and recurrent costs (US \$ Thousands, 1977)

\begin{tabular}{|c|c|c|c|c|c|c|c|c|}
\hline & \multicolumn{3}{|c|}{ Investment Cost per } & \multicolumn{5}{|c|}{ Recurrent Cost per } \\
\hline & $\mathrm{RHC}$ & RD & DIV & $\mathrm{RHC}$ & $\begin{array}{c}1977 \\
\mathrm{RD}\end{array}$ & DIV & $\begin{array}{l}1979 \mathrm{p}^{\mathrm{b}} \\
01 \mathrm{~V}^{-}\end{array}$ & $\begin{array}{c}1981 p^{b} \\
0 I V^{b}\end{array}$ \\
\hline Construction ${ }^{c}$ & 79 & 6 & 127 & & & & & \\
\hline Trainıng & 20 & 6 & 68 & & & & & \\
\hline Durables & 20 & 5 & 60 & & & & & \\
\hline Nondurab les & 5 & 0.5 & 9 & 10 & 2 & 20 & 33 & 39 \\
\hline Salaries & & & & 9 & 2 & 25 & 25 & 28 \\
\hline Buildng and Mazntenance & & & & 5 & 1 & 13 & 16 & 19 \\
\hline Replacement Trainung & & & & 3 & 1 & 11 & 11 & 13 \\
\hline Total & 124 & 17.5 & 264 & 27 & 6 & 75 & 85 & 99 \\
\hline
\end{tabular}

a One Division, composed of a Rural Health Center and eight (average) associated Rural Dispensaries serving 50,000 people.

$b \quad p=$ Projections, based on the assumptions that costs for:

Nondurables will be varlable, increasing roughly in direct relation to visits/person/year;

Salaries " " fixed, " moderately after the capacity of 1977 staffing levels is exceeded by patient demand;

$B$ and $M$ " variable

as increased utllization leads to degradation faclities, increasing the need for repait and maintenance;

Replacement " " fixed Training moderately as staffing levels increase.

$c$ The useful 11 fetimes of service facilitics might be taken into consideration for purposes of estimating depreciation. In this case this has not been done since the major investment itemsfacilities-can be maintained for long, useful life. Also for purposes of budgeting or financzal planning, replacement costs for these items need only be considered in the year in which they occur, rather than on distributed basis.

data $[2,16,17]$. This trend has been fundamental in the development of the rural health system, and reflects Government policy as well as the increased availability of and prominent role played by external funding (Table 3).

Overall, it is clear that external assistance is primarily oriented by the Government of Tanzania toward investment activities, and recurrent costs are almost solely the domain of the host country-adding more strength to the argument that the ongoing operation of rural health services must be structured in such a way as to be within the financial means of the host country. A very practical approach to the problem of transferring the responsibility for recurrent costs was used by USAID in the newly-introduced MCHA training program. In this case, a sliding scale $(20 \%, 40 \% \ldots)$ was used over the first five years of each school's operation to gradually turn over all recurrent financing from USAID to the Tanzanian Government.

Our micro-level estimate that per capita investment costs were 3.5 times higher than yearly recurrent costs clearly indicates that investment deserves careful consideration in planning and financing, and that LDCs are more likely to require assistance in this area.

Recurrent costs as calculated at the micro level-US $\$ 1.50$ per person per year and $\$ 0.32$ per visit-are substantially higher than the $1976 / 77$ budget-based figure at the macro level-US $\$ 0.80$ per year and $\$ 0.17$ per visit. Since the micro-level estimate is based on specific expectations for staff and services (and therefore more likely to be a true reflection of actual cost than the macro-level estimate), these results suggest that the level of services possible to finance with the budget then in use was somewhat less than planned. This is consistent with our earlier finding that limited availability of $\mathrm{MCH}$ services is related to $70 \%$ of target utilization levels, though the two are not necessarily causally related.

It should be noted that the budget for rural health services expanded 50\% between FY 1977 and 1978 (Table 3), bringing the per capita recurrent budget to approx. US $\$ 1.20$, closer to our estimated $\$ 1.50$ per capita recurrent cost at plan. According to our analysis, this increase is in line with defined policies and with needs.

With regard to the effects of coverage and utilization (the latter as an expression of effectiveness) on recurrent costs, an increase of $13 \%$ (from US $\$ 1.50$ to $\$ 1.70$ per capita per year based on data in Table 4) is estimated in response to a utilization increase of $28 \%$ (from 4.7 to six visits per capita per year) between 1977 and 1979. The cost per visit should coincidentally decrease by $10 \%$ (from US \$0.32 to \$0.29). Per capita annual costs in 1981 may have risen to nearly $\$ 2$ in constant dollars, or nearly $\$ 3$ in current (1981) dollars, assuming prices in this sector have increased at approx. 15\% per year since 1977 (consistent with price indices reported to the IMF).

Breaking down recurrent costs, a picture emerges from this analysis which is quite different from common budgeting for or financing of primary health care services in developing countries. Our observations in LDCs indicate that budgeted costs of nondurable goods are of ten grossly inadquate, sometimes as low as $10 \%$ of total operating costs. This is no doubt an important cause of the often inadequate utilization of primary health care services, and commonly results from disproportionately high recurrent expenditures for manpower-sometimes 
$80 \%$ of recurrent costs. Other cost components, such as building and maintenance and recurrent training, are often equally under-financed.

In this analysis (micro-level), total recurrent costs were made up $35 \%$ by nondurables, $33 \%$ by salaries, $17 \%$ by building and maintenance and $15 \%$ by replacement training. The total cost of nondurables is estimated to increase by $27 \%$ between 1977 and 1979 , and become $39 \%$ of total recurrent costs.

While firm conclusions about appropriate recurrent budgeting and cost levels would require a comprehensive review of hard evidence from many cases (not available), it appears here that it is possible to face relatively low recurrent costs for rural health services even when allocating what we believe to be adequate proportional amounts for all elements of recurrent costs. Tanzania has chosen admirable resource allocations within the rural health sector, perhaps a cause of their high attendance records at rural health facilities.

\section{SUMMARY}

Within the framework of cost analysis of Primary Health Care projects assisted by the U.S. Agency for International Development in a number of developing countries, the authors applied basic principles of cost, coverage and utilization analysis to Primary Health Care Services in the first two echolons (the Rural Dispensary and the Rural Health Center) of the health care system in Tanzania. From the analysis it is evident that it is possible for Tanzania to implement a relatively effective, well-organized rural health care system at operating (recurrent) costs of roughly US\$1.50 per capita per year (1977 US dollars) for an investiment cost of slightly over $\$ 5$ per capita. These results may be applicable to other developing countries of similar economic stature to Tanzania, though would be expected to differ according to the organization of services, and levels of material and labor costs. This analysis adds further strength to the argument that developing countries need economic assistance with the start-up of such programs, for which they subsequently face much more moderate recurrent costs. Cost analysis is inadequately applied to government operations in general and health service operations in particular. Essential aspects of a methodology for cost and coverage analysis of such services in developing countries are presented. Availability of considerable program-specific data allowed a detailed analysis of geographic coverage, health care needs and utilization for the MCH sector.

\section{REFERENCES}

1. W. K. Chagula and E. Tarimo, Meeting basic health needs in Tanzania. In Health by the People (Edited by K. Newell), pp. 145-168. World Health Organization, Geneva (1975).

2. R. M. Titmuss et al., The Health Services of Tanganyika, pp. 179, 195. Pitman Medical, London (1964).

3. G. M. van Etten, Rural Health Development in Tanzania, pp. 17-46. Van Gorcum, Assen/Amsterdam (1976).

4. R. N. Grosse and B. H. Perry, Correlates of life expectancy in less developed countries. Health Policy and Education 2, 275-304 (1982).

5. S. H. Rajab, Unpublished report.

6. MCH Services, Unpublished report.

7. D. C. Morley et al., Measles in East and Central Africa. East Afr. Med. J. 44, 497-508 (1967).

8. H. J. L. Burgess et al., The nutritional status of young children in Hombolo, Tanzania. East Afr. Med. J. 45, 605612 (1968).

9. A. E. J. Masawe and H. Nsanzumuhire, Scabies and other skin diseases in pre-school children in Ujamaa villages in Tanzania. Trop. Geogr. Med. 27, 288-294 (1975).

10. J. P. Vaughan et al., Anaemia in a coastal area of Tanzania. East Afr. Med. J. 50, 86-93 (1973).

11. WHO, unpublished country profile, 1977.

12. T. Tanahashi, Health service coverage and its evaluation. Bull. WHO 56, 295-303 (1978).

13. A. Donabedian, Aspects of Medical Care Administration: Specifying Requirements for Health Care, p. $425 \mathrm{ff}$. Harvard University Press, Cambridge (1973).

14. Measurement of Coverage, Effectiveness and Efficiency of Different Patterns of Health Care, SHS/78/1. World Health Organization, Geneva.

15. The Ministry of Health, The United Republic of Tanzania, Primary health care: Tanzanian experience, p. 4. Submitted to the International Conference on Primary Health Care, Alma-Ata, U.S.S.R., 6-12 September (1978).

16. 0. Gish, Planning the Health Sector: the Tanzanian Experience. Croom Helm, London (1975).

17. H. R. Caldwell and D. W. Dunlop, An empirical study of health planning in Latin America and Africa. Soc. Sci. Med. [Med. Econ.] 13C, 75-86 (1979).

18. J. S. Yudkin, The economics of pharmaceutical supply in Tanzania. Int. J. Health Serv. 10. 455-477 (1980). 